\title{
Law Making Treaties: The Implication of International Law towards Indonesia's Legislations
}

\author{
Rudi Natamiharja ${ }^{\star}$ Rudy ${ }^{\star \star}$; Chaidir Ali ${ }^{\star \star \star}$ \\ *International Law Department, Faculty of Law, Universitas \\ Lampung \\ rudi.natamiharja@fh.unila.ac.id \\ ${ }^{\star \star}$ Constitutional Law Department, Faculty of Law, \\ Universitas Lampung \\ rudy.1981@fh.unila.ac.id \\ ${ }^{\star \star \star}$ Research and Dedication Department, Universitas \\ Lampung \\ chaidirali678@gmail.com
}

\begin{abstract}
In relation to promoting global issues in international forums, several sources of international law are formed. These formed laws are in the figure of law-making treaties, which are closely related to international regimes that influence the behavior of international actors. However, in developing countries, such as Indonesia, International law is considered the outermost layer of the legal order under national law, colonial law, religious law, and customary law. Thus, it is a challenge for international laws to be enforced in a broad society. Therefore to make international law hold an implementative power, the laws need to be adopted in the national law. This article aims to examine the implication of international laws, especially in international treaties towards Indonesia legislation. It is carried out by mapping a series of international treaties ratified and enacted through national laws in Indonesia. The results of this study demonstrates that until 2019 the
\end{abstract}


Indonesian Government has bound itself in 302 agreements. From the 302 treaties, only 61 international treaties were Law-Making Treaty, and only UNCLOS 1982 has implicated by the Indonesian Government through Law No. 32 of 2014 concerning Maritime Law.

Keywords: International treaties; Legislation; Law Making Treaty.

\section{A. Introduction}

The international law source as the object of this research is an international treaties from the law making treaty. Although in the context of the definition are still in doubts regarding whether the agreement can produce law as said by Catherine Brolmann. ${ }^{1}$ However, in her defense of the law-making terminology, Catherine Brolmann argues refers to the content of international treaties are more regulating character rather than seen as mere contractual legal acts. ${ }^{2}$

International law which sources by law making treaty has an impact in the establishment of a new legislation order as a response to the law making treaty itself. As stated by David Haljan described that law making treaty plays a role in:

"They intend to establish directly specific legal rights in national legal systems for private actors. Other types of treaty, addressing state actors explicitly and solely, may nevertheless aim to adjust government policy or conduct and require amending current rights by legislation."3

The law making treaty is intended to establish certain legal rights for private (non-state) or state actors, and even to harmonize government policies through the formation of new legislation. Law making treaty as a source of international law has a fundamental impact on the legislation development.

Indeed, the national legislation program is currently the method of developing Indonesian legislation. It puts the ratification of international treaties as one objects included in the open cumulative

1 Catherine Brolmann, "Law Making Treaties: Form and Function in International Law”, Nordic Journal of International Law, vol 74, 2005, p. 383-404.

2 Ibid.

3 David Haljan, Separating Powers: International Law Before National Courts, The Hague: TMC ASSER PRESS, 2013, p. 30 
list. ${ }^{4}$ It shows that Indonesia's involvement in international law is a responsive manner by not taking time to wait for the involvement in an international treaties.

However, studies related to the development of legislation do not always take a side with international law. As one example, in a recent study related to the real legal certainty in developing countries conducted, Michiel Otto demonstrated that the placement of international law as a legal entity in the fifth layer / outermost layer of the legal order that has legal certainty for people or citizens in development countries.

In his research, Jean Michiel Otto stated in the general, law in development countries was historically formed by four layers. ${ }^{5}$ The innermost layer consists of customary law recognized (as law by the local society), the above are the layers of religious rules, then the colonial state legal rules and the next layer is the modern national law which continues to develop, and the outer layer is international law. ${ }^{6}$ In order to make it easier to understand Jean Michiel Otto's opinion, it can be illustrated through the figure of legal certainty in development countries as follows:

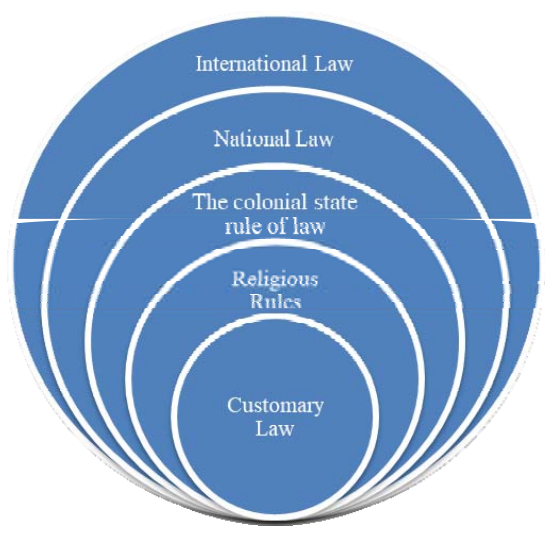

4 Article 23 of Law Number 12 on 2011 concerning the Formation of Legislation.

5 Jean Michiel Otto, Kepastian Hukum yang Nyata di Negara Berkembang, dalam Kajian Sosio Legal, ed. Adriaan W. Bedner et. al. Denpasar: Pustaka Larasan, p. 119.

6 Ibid. 
It is learnt from the figure abov that in order to make the international law have an implementative power in developing countries, it needs to be adopted in national laws. With respect to it, this article aims to examine the implication of international laws especially in the form of international treaties towards Indonesia legislation. It is carried out by mapping series of international treaties ratified and enacted through national laws in Indonesia.

Indonesia as an independent country has made the spirit of internationalism in one of its goals. It has been clear from the flashback when the Investigating Committee for Preparatory Efforts of Indonesian Independence (BPUPKI) wished to formulate the basis of an independent Indonesia where Soekarno proposed internationalism or humanity as one of the foundations in the Indonesian state. Referring to the Pancasila's formulation as the ideology agreed upon in the 1945 Constitution Preamble of the Republic Indonesia, the notion of internationalism was not written in the Pancasila text. Even so, the spirit of internationalism still echoes in the Indonesia goals.

The spirit of internationalism as one of the independent Republic of Indonesia goals is evidence by the formulation in the fourth paragraph of the 1945 Indonesian Constitution which reads "... and participate in implementing world order based on independence, eternal peace and social justice ...". It is evidence that the Republic of Indonesia views the spirit of internationalism in the form of independence, eternal peace and social justice. In addition, this is one of the goals in the establishment of an independent Republic of Indonesia.

Concrete steps are needed in order to put the Indonesia goals into reality. One of them is Indonesia's involvement in the international law development. Indonesia's participation in international relations is based on lawmaking treaty in international treaties. United Nations Conventions on the Law of the Sea (UNCLOS), International Convention on Civil and Politic Rights (ICCPR) and the Convention on the Elimination All Form of Discrimination against Women (CEDAW) are among the forms of international laws where Indonesia was involved. 
Furthermore, the spirit of internationalism is addressed in the Preamble of the 1945 Constitution of the Republic of Indonesia which requires Indonesia participate in implementing world order based on independence, eternal peace and social justice. Indeed, the international law followed by Indonesia would certainly not make such a supra-national order which results in Indonesian national law to being under or lower than the international instrument. Therefore, the development of Indonesian legislation, in one side, and the implication of international laws towards Indonesia legislations, in another, are something to be answered. The implication from the mapping carried out in this paper concerns with the Indonesia's ability to enforce international law through other legal instruments.

This article applies a socio legal approach in its descriptive qualitative methods through literatures. In addition to literature studies, Meuwissen's theoretical approach is also used relying on his argument that the formation of legislation distinguishes two central moments in the formation of law, namely political-ideal moments and technical moments. Political-ideal moments is relate to the desired legislation content, namely relating to articulating or cultivating political objectives, while technical moments are related to the technical legal drafting process. ${ }^{7}$ These two moments create complexity in the legislation. The complexity of developing legislation is in line with D'Anjou argument, in Satjipto Rahardjo, ${ }^{8}$ that the development of legislation is a complex process. This complexity ${ }^{9}$ becomes an important spotlight in the context to follow-up a legislation and to simplify the viability.

This article concerns with problems of legislation in Indonesia with respect to the International law which reflects in to two questions; to what extent has the mapping of international treaties with

7 B Arief Sidharta, Meuwissen Tentang Pengembangan Hukum, Ilmu Hukum, Teori Hukum dan Filsafat Hukum, Bandung: Refika Aditama, 2007, p. 10.

8 Satjipto Rahardjo, "Merumuskan Peraturan Hukum", Papers in PDIH Undip Student Reading Materials, Semarang: PDIH, 5 January 2007.

9 Robert B. Seidmann et.all., Legislative Drafting for Democratic Social Change: A Manual for Drafters, First Published, London: The Hague Boston, Kluwer Law International Ltd., 2001, p. 15. 
law making treaty character been implemented by Indonesia? And how is the legislation classified as the result of the international law ratification?

\section{B. Result and Discussion}

\section{The Characteristics of International Treaties}

According to the Vienna Convention on the Law of Treaties 1969 in Article 2 paragraph (1) sub a, what is meant of the treaties is an international agreement made between countries in written form and governed by international law, whether embodied in a single instrument or in two or more related instruments and any special designation. ${ }^{10}$ Meanwhile, according to Law Number 24 of 2000 concerning International Treaties, the international treaties is defined as an agreement, in a specific form and name, which is in written and regulated in international law, and raises the rights and obligations in the field of public law. ${ }^{11}$

International treaties are one of the sources of international law as confirmed in Article 38 paragraph (1) of the International Court of Justice Statute. The Statute mentioned international treaties as one of the main sources of international law which has an important and very rapid role in its development

In Indonesia, it is known by one term for various types of international treaties, whereas each treaty term has its own characteristics. Some terms commonly used are treaty, convention, declaration, charter, protocol, pact, agreement, statute, covenant, ${ }^{12}$ and others. According to Myers, there are approximately thirty-nine names used for international treaties, among them are treaty, pact, constitution, charter, convention, agreement, exchange of notes, memoranda of agt., Protocol, act / final / general, declaration, notes verbales, ar-

10 Vienna Convention on the Law of Treaties 1969.

11 Law Number 24 Year 2000 Concerning International Treaties.

12 B. Maryati, "Aspek-Aspek Hukum Perjanjian Internasional Dan Kaitannya Dengan MoU Helsinki”, Jurnal Humaniora: Jurnal Ilmu Sosial, Ekonomi dan Hukum, Vol. 1 Num. 1, 2017: 30-39. 
rangement, accord, additional articles, aide-memoire, code, communique, compact, contract, instrument, lease, mandates, measaures, minute/agreed, modification, modus vivendi, optional clause, plan, process-verbal, provisions, recommendation, resolution, regulations, rules, scheme, statutes, understandings, and undertakings. ${ }^{13}$

The difference in naming of international treaties shall not diminish the rights and obligations contained in the treaties. They only state that the substance of the treaties has a different hierarchy cooperation type or to state the link between the other previous international treaties. ${ }^{14}$

Regarding the types of international treaties which are widely used by many countries today, the followings are the types one may refer to: ${ }^{15}$

1. Treaties

The treaties includes the notion of an international treaty in generally but it is specifically defined as a very formal and essential international agreement and generally used for multilateral agreements. However, in the application has no similirity and apply in the bilateral agreements.

2. Convention

Conventions are also generally defined as all forms of international treaties, so their meaning can be interpreted the same as the meaning of treaty. Conventions are used in multilateral international treaties, which involve many parties.

3. Agreement

Agreement is a form of treaties that has a position under the treaty and convention. Generally used for bilateral international

13 DP Myers, "The Names and Scope of Treaties", American Journal of International Law, Vol. 51 Num. 3, 1957: 574-605.

14 H. Hilda, "Kedudukan dan Daya Mengikat Konvensi Denhaag 1954 Tentang Perlindungan Obyek Budaya Dalam Sengketa Bersenjata Terhadap Pihak-Pihak Yang Bersengketa (Amerika Serikat-Irak) Menurut Konvensi Wina 1969 Tentang Perjanjian Internasional”, Jurnal Cita Hukum, Vol. 1 Num. 1, 2013.

15 Departemen Luar Negeri, "Pelatihan Pembuatan Kontrak Internasional”, Surabaya. (Makalah), 2002. 
agreements which regulate in the basics of a global cooperation. However, it can be used in a limited way in multilateral agreements.

4. Charter

Naming international treaties with a charter is usually contains in the international organization constitution. The examples are include in the Charter of the United Nations as a charter from the United Nations or African Unity Organization which the charter named is the Charter of the African Unity, and Charter of the American States, 1948.

5. Protocol

Unlike treaties and conventions, protocols are unformal international agreement. Generally protocols are used to add the clauses of the convention. Starke is further explains the use of the term protocol in several categories, namely:

a. Protocol as an additional instrument of a convention was made by the negotiating party, which has the same degree as the convention itself. The protocol is known as protocol of signature which contains the interpretations or clauses of the convention or as additional provisions of a lower degree, or as formal clauses that are not included in the convention.

b. Protocol is an auxiliary instrument to a convention that has an independent status and entry into force and subject to the ratification of the convention itself. Generally, it was not made in the same time as the formulation of the convention text.

c. Protocol as an agreement which has the same characteristic and position as a convention.

d. Protocol as a mutual of understanding record between the parties regarding certain matters which is better known as "verbal process".

6. Declaration

Declaration is also defined as an agreement which contain a general resolutions. The parties of the declaration is commit to carry out these policies in the future. The Declaration has little 
and concise content, and set aside a formal provisions such as the need for a "Power of Attorney", or qualification requirements.

7. Memorandum of Understanding (MoU)

The term of MoU is refers to the unformal agreement with a strong technical element. However, in its further development, the $\mathrm{MoU}$ is also often used in formal international agreements.

In practice, the treaties made in a way signing of $\mathrm{MoU}$ is preferable because it is considered as a simple agreement, and can be made as an umbrella for an agreement or as an implementiation of agreement which regulate technical matters. Due to its simplicity, the MoU is generally not ratified.

International treaties becomes a primary source of international law since it outlines rights and obligations of the state parties. Essentially, the international treaty consist of general clauses to meet the legal needs of the parties at that time. Therefore, the choice of wheter or not to become a party to a treaty is entirely up to the state party. Thus, if the state party chose to adopt the international treaties, the national government will take further implication effect by ratifiying the treaty to its national law.

\section{The Concept of Law Making Treaty}

According to Mochtar Kusumaatmadja, international agreements as a source of international law are classified into two groups, namely: ${ }^{16}$

1. bilateral agreements and multilateral agreements.

2. agreements in treaty-contracts and law-making treaty.

Treaty-contracts is an agreement that comprises such agreements as in civil law, namely a contract or agreement that only creates the rights and obligations for the parties who involve to the agreement. It was once carried out by Indonesia in its agreement with the Slovak Republic regarding the exchange of information and cooperation in nuclear safety (Agreement between the Nuclear energy Regulatory Agency of the Republic of Indonesia and the Nuclear Regulatory

16 U. Usmawadi, “Status Indonesia dalam Space Treaty 1967”, Jurnal Hukum \& Pembangunan Vol. 16 Num. 6, 2017: 630-637. 
Authority of the Slovak Republic for the Exchange of Technical Information and Cooperation in Nuclear Safety, Jakarta, 11th October 2011). ${ }^{17}$ Another agreements had also been made between Indonesia and the People's Republic of China regarding dual citizenship in 1955-1969.

Meanwhile, the concept of Law-Making Treaties itself is viewed as an output of law in the agreement product. It is different from legal products in general. For example, laws which require an academic draft in the process before it becomes law. Law-Making Treaties are made from multilateral agreements. It is policy that regulates the characteristic Indonesian law.

Another characteristic of Law-Making Treaties is that the agreement may involve many countries as participants. Although not all articles have benefit for every participant, Law-Making Treaties is considered the fairest decision and one of the rule-making tool in international relations.

Because of their character as 'treaties', the articles in the LawMaking Treaties agreement are transformed into positive legal provisions with tend to must fulfilled obligations, in contrast to coercive laws.

The concept of Law-Making Treaties is closely related to the 'international regime'. The international regime is an international organization that influences the behavior of states and other international actors. So the Law-Making Treaties is the result of it. For example, the law of the sea. UNCLOS 1982 is an international agreement in the form of Law-Making Treaties and followed by many countries in the world, so it is multilateral treaty.

Nevertheless, international law is a unique law with its own characteristics, scope, and the way of making society in a legal order. Law-Making Treaties is an ideal way of creating provisions in the international community. In international relations, the subject of a Law-Making Treaties is a state, so there is no need to doubt the validity of a Law-Making Treaties.

17 Accessed from https://kemlu.go.id/b-02/id/pages/hubung_bilateral_indonesia_dan_slovakia/1283/etc-menu on April 13, 2020 at 19.00 WIB. 
The most fundamental difference between treaty-contracts and Law-Making Treaties is the involvement of third parties who do not participate in negotiations. In a treaty, a third party cannot participate in the agreement without the consent of the contract maker. Whilest, in the Law-Making Treaties, because the regulation has a broad and general problem regarding all members of the international community, a third party or other party can be bound by the agreement even though they do not participate in the negotiations.

\section{Transformation of Law-Making Treaty into National Law}

The transformation of international treaties categorized as LawMaking Treaty into national law may result in pros and cons. There are ones who think that it is necessary to transform international treaties into statutory regulations and there are others who hold opposite opinion that there is no need to do so.

As Mochtar Kusumaatmadja has suggested, Indonesia does not adhere to the theory of transformation, so that an international agreement will automatically be binding without transformations. This argument is based on the fact that Indonesia is more inclined with the Continental European system. It is considered directly binding to the obligation for implementation and obedience with all agreements and the provisions of the conventions that have been ratified without any legislation process anymore. However, it is necessary to enact a national law if a change in the national law is needed which directly concerns the rights of citizens as individuals.

The fundamental reason for the transformation is that the international treaties are categorized as law-making which is aimed at changing the provisions that are applicable in a country. The obligation to carry out the transformation in international agreements is categorized as law making, often mandated in written. For example, Article XVI paragraph (4) of the WTO Agreement states:

"Each Member shall ensure the conformity of its laws, regulations and administrative procedures with its obligations as provided in the annexed agreements". 
Likewise, Article 4 paragraph (1) of the Convention against Torture and Other Cruel, Inhuman or Degrading Treatment or Punishment, states that, "Each State Party shall ensure that all acts of torture are offenses under its criminal law". ${ }^{18}$

The reason of the ratification of a provision cannot be used as the basis for the entry into force of an international agreement in a legal process at the national level. Ratification is a form of binding an agreement. Therefore it becomes the basis for the obligation to transform the contents of the international agreement into national law. However, there are still different opinions regarding the implementation issues whether it requires implementing regulations or not. ${ }^{19}$

In ratifying the Law-Making Treaty, there are two obligations that must be carried out by the state, namely ensuring the harmony of international agreements with the constitution. In this case, Indonesia shall ensure conformity with the 1945 Constitution and transform international agreements into national law. This harmony is intended by the 1945 Constitution as a basis, because it is the highest norm in the hierarchy of Indonesian legislation. In addition, it also shall ensure the common perception of the government and people and avoid veiled intervention by other countries over the country's sovereignty, considering that international agreements are often used as political instruments by one country against another. ${ }^{20}$

\section{Indonesia's Participation in Various International Agreements}

Since its independence on 17 August 1945, Indonesia has followed various international agreements, both bilateral and multilateral. Of the 302 (three hundred and two) international agreements that have been ratified by Indonesia from 1947 to 2019, there are at least 61 international agreements, which are Law-Making Treaty in nature.

18 H. Juwana, "Kewajiban Negara dalam Proses Ratifikasi Perjanjian Internasional: Memastikan Keselarasan dengan Konstitusi dan Mentransformasikan ke Hukum Nasional”, Undang: Jurnal Hukum, Vol. 2 No. 1, 2019, p. 1-32.

19 https: / www.hukumonline.com/klinik/detail/ulasan/lt4c69b1cbd0492/ status-hukum-uu-rasiikasi/ Accessed on April 13, 2020 at 19.00 WIB.

20 Ibid. 
It is learnt from the elaboration above, Law-Making Treaty is different from Treaty-contracts. Law-Making Treaties is required through the affirmation of legal products as the output of this agreement. It does not need to be based on a special study in the form of an academic text. Rather, the Law-Making Treaties are made from multilateral agreements. It is a policy that regulates the nature of the law in Indonesia.

In addition, Law-Making Treaties involves many countries as participants in it. Although not all articles benefit every participant, Law-Making Treaties is considered the fairest decision and one of the rule-making tools in international relations. The articles in the LawMaking Treaties agreement are transformed into positive legal provisions, tend to be "obligations" that must be comply with, instead of compelling laws.

The most fundamental difference between treaty-contracts and Law-Making Treaties is the involvement of third parties who do not participate in negotiations. In a treaty, a third party cannot participate in the agreement without the consent of the contract maker. Whereas in Law-Making Treaties, because what is regulated is a general problem regarding all members of the international community, third parties or other parties can participate in the agreement even though they do not participate in the negotiations.

In the following table, the author presented the 61 international treaties that have been ratified by Indonesia which are Law-Making Treaty:

\begin{tabular}{|c|c|c|c|c|}
\hline No & Treaty & Year & $\begin{array}{c}\text { Indonesia } \\
\text { Legislation }\end{array}$ & $\begin{array}{c}\text { Concen- } \\
\text { tration }\end{array}$ \\
\hline 1. & $\begin{array}{l}\text { Membership of Indonesia to the Interna- } \\
\text { tional Monetary Fund (IMF) and Inter- } \\
\text { national Bank for Reconstruction and } \\
\text { Development, (IBRD) }\end{array}$ & 1966 & NA & Economic \\
\hline 2. & $\begin{array}{l}\text { Agreement Establishing the Southeast } \\
\text { Asian Fisheries Development Centre with } \\
\text { Protocol }\end{array}$ & 1967 & NA & $\begin{array}{l}\text { Natural } \\
\text { Resouces }\end{array}$ \\
\hline 3. & $\begin{array}{l}\text { Approval of the Government of the } \\
\text { Republic of Indonesia to the Articles of } \\
\text { Agreement of the International Monetary } \\
\text { Fund is Updated }\end{array}$ & 1968 & NA & Economic \\
\hline
\end{tabular}




\begin{tabular}{|c|c|c|c|c|}
\hline 4. & $\begin{array}{l}\text { Special Drawing Rights to the Internation- } \\
\text { al Monetary Fund }\end{array}$ & 1969 & NA & Economic \\
\hline 5. & $\begin{array}{l}\text { Agreement for the Facilitation of Search } \\
\text { for Aircraps in Distress and Rescue of Sur- } \\
\text { vivors of Aircraft Accident }\end{array}$ & 1972 & NA & $\begin{array}{l}\text { Disaster } \\
\text { Manage- } \\
\text { ment }\end{array}$ \\
\hline 6. & $\begin{array}{l}\text { Multilateral Agreement on Commercial } \\
\text { Rights on Non-Scheduled Air Services } \\
\text { among the Association of South East } \\
\text { Asian Nations }\end{array}$ & 1973 & NA & Politic \\
\hline 7. & $\begin{array}{l}\text { Agreement on the Establishment of the } \\
\text { ASEAN Secretariat }\end{array}$ & 1976 & NA & Politic \\
\hline 8. & $\begin{array}{l}\text { Treaty of Amity and Cooperation in South } \\
\text { East Asia (TAC) }\end{array}$ & 1976 & NA & Politic \\
\hline 9. & Agreement on the ASEAN Food Security & 1980 & NA & $\begin{array}{l}\text { Disaster } \\
\text { Manage- } \\
\text { ment }\end{array}$ \\
\hline 10. & $\begin{array}{l}\text { Supplementary Agreement to the Basic } \\
\text { Agreement on ASEAN Industrial Projects, } \\
\text { ASEAN Urea Project (Indonesia) }\end{array}$ & 1981 & NA & Economic \\
\hline 11. & $\begin{array}{l}\text { Reserve Basic Agreement on ASEAN } \\
\text { Industrial Projects }\end{array}$ & 1981 & NA & Economic \\
\hline 12. & $\begin{array}{l}\text { ASEAN Agreement on the Conservation } \\
\text { of Nature and Natural Resources }\end{array}$ & 1985 & NA & $\begin{array}{l}\text { Natural } \\
\text { Resouces }\end{array}$ \\
\hline 13. & $\begin{array}{l}\text { United Nations Convention On The Law } \\
\text { Of The Sea }\end{array}$ & 1985 & $\begin{array}{l}\text { The Law } \\
\text { No. } 32 \text { / } \\
2014\end{array}$ & $\begin{array}{l}\text { Natural } \\
\text { Resouces }\end{array}$ \\
\hline 14. & $\begin{array}{l}\text { Agreement on ASEAN Energy Coopera- } \\
\text { tion }\end{array}$ & 1987 & NA & Energy \\
\hline 15. & $\begin{array}{l}\text { Agreement on the Preferential Shortlisting } \\
\text { of ASEAN Contractors }\end{array}$ & 1988 & NA & Economic \\
\hline 16. & $\begin{array}{l}\text { Protocol for Implementing the Fourth } \\
\text { Package of Commitments in the Field of } \\
\text { Financial Services in the Approval of the } \\
\text { ASEAN Framework on Services }\end{array}$ & 2008 & NA & Economic \\
\hline 17. & $\begin{array}{l}\text { Amendments to the Agreement regarding } \\
\text { the Establishment of an ASEAN Promo- } \\
\text { tion Center in the Field of Trade, Invest- } \\
\text { ment and Tourism }\end{array}$ & 2008 & NA & Economic \\
\hline 18. & $\begin{array}{l}\text { Charter of the Association of Southeast } \\
\text { Asian Nations }\end{array}$ & 2008 & NA & Politics \\
\hline 19. & $\begin{array}{l}\text { Protocol for Implementing the Sixth Pack- } \\
\text { age Commitment in the Asean Framework } \\
\text { Agreement in Services }\end{array}$ & 2008 & NA & Economic \\
\hline 20. & $\begin{array}{l}\text { Protocol to Amend Article } 3 \text { (Amendment) } \\
\text { of the ASEAN Framework Agreement on } \\
\text { Integration of Priority Sectors }\end{array}$ & 2008 & NA & Economic \\
\hline
\end{tabular}




\begin{tabular}{lllll}
\hline 21. $\begin{array}{l}\text { Protokol Integrasi Sektor-Sektor ASEAN } \\
\text { untuk Sektor Jasa Logistik }\end{array}$ & 2008 & NA & Economic \\
\hline $\begin{array}{l}\text { Protocol } 2 \text { on Freedom of the Right } \\
\text { of Transport, Third, Fourth and Fifth } \\
\text { Indefinitely at All Points via International } \\
\text { Airports in ASEAN }\end{array}$ & 2009 & NA & Economic \\
\hline 23. $\begin{array}{l}\text { ASEAN Multilateral Agreement on Com- } \\
\text { plete Freedom of Air Transport Services }\end{array}$ & 2009 & NA & Economic \\
\hline $\begin{array}{l}\text { Protocol } 3 \text { on Freedom of the Third and } \\
\text { Fourth Unrestricted Transport Rights in } \\
\text { the ASEAN Sub-Region }\end{array}$ & 2009 & NA & Economic \\
\hline 25. $\begin{array}{l}\text { ASEAN Multilateral Agreement on Air } \\
\text { Transport Services }\end{array}$ & 2009 & NA & Economic \\
\hline $\begin{array}{l}\text { Protocol } 4 \text { on the Fifth Unrestricted } \\
\text { Freedom of the Right to Transport in the } \\
\text { ASEAN Sub-Region }\end{array}$ & 2009 & NA & Economic \\
\hline $\begin{array}{l}\text { Protocol } 5 \text { on Freedom of the Third and } \\
\text { Fourth Unrestricted Transport Rights } \\
\text { among ASEAN Capitals }\end{array}$ & 2009 & NA & Economic \\
\hline $\begin{array}{l}\text { Protocol } 6 \text { on the Fifth Unrestricted } \\
\text { Freedom of the Right to Transport among } \\
\text { ASEAN Capitals }\end{array}$ & 2009 & NA & Economic \\
\hline $\begin{array}{l}\text { Protocol } 1 \text { on Freedom of the Right to } \\
\text { Transport, Third, Fourth and Fifth Indefi- } \\
\text { nitely in Designated Points in ASEAN }\end{array}$ & 2009 & NA & Economic \\
\hline $\begin{array}{l}\text { Protocol for Implementing the Seventh } \\
\text { 26 }\end{array}$ & & & \\
\hline
\end{tabular}

Protocol for Implementing the Seventh

30. Package of Commitments in the ASEAN 2009 NA Economic Framework Agreement on Services

Memorandum of Understanding between

Governments of Member States of the

31. Association of Southeast Asian Nations
(ASEAN) Participants in the Second Pilot 2010 NA $\quad$ Economic

Project for the Implementation of the

Regional Self-Certification System

32. ASEAN Trade in Goods Agreement

2010 NA

Economic

Protocol for the Implementation of the

Fifth Package of Commitments on Finan-

33. cial Services under the ASEAN Framework 2011 NA Economic Agreement on Services

Protocol 2 on Fifth Unrestricted Freedom

34. of the Right to Transport in All ASEAN 2011 NA Economic Cities

Protocol 1 on Third and Fourth Unrestrict-

35. ed Freedom of Transport Rights among 2011 NA Economic All ASEAN Cities 
36. ASEAN Multilateral Agreement on Full Freedom of Air Transport Passengers

2011 NA

Economic

Second Protocol to Amend the Agreement

on Trade in Goods in the Framework

37. Agreement on Comprehensive Economic

Cooperation between the Association of

2011 NA

Economic

Southeast Asian Nations and the People's

Republic of China

38. Protocol on Implementation of the Eighth

38. Package Commitments to the Framework 2011 NA Economic Agreement on Services

39. Protocol 2 on the Fifth Unrestricted

Freedom of the Right to Transport in the 2011 NA Economic ASEAN Sub-Region

40. Protocol 1 on Third and Fourth Unre-

stricted Freedom of Transport Rights in 2011 NA Economic the ASEAN Sub-Region

Protocol 1 concerning Third and Fourth

41. Unrestricted Freedom of Transport Rights

between All Points in the Contracting

2012 NA

Economic Parties

42. Third Protocol to Amend the Treaty of

42. Friendship and Cooperation in Southeast 2012 NA Politic Asia

Protocol for Implementing the Sixth Pack-

43. age of Air Transport Services Commitments in the ASEAN Framework Agree-

2012 NA

Economic ment on Services

44. ASEAN Comprehensive Investment Agreement

2012 NA

Economic

Memorandum of Understanding between the Member Governments of the Associa-

45. tion of Southeast Asian Nations (ASEAN) on the Second Pilot Project for the Imple-

2013 NA Economic mentation of a Self-Regional Certification System

Approval of the Establishment of the

46. ASEAN + 3 Macro Economic Research 2014 NA Economic Office (AMRO)

47. ASEAN Approval in the Customs sector 2014 NA $\quad$ Economic
Agreement on the Establishment of an Disaster

48. ASEAN Coordinating Center for Humani- 2014 NA Managetarian Assistance in Disaster Management ment 
The Framework of Agreement on Partner-

ship and Comprehensive Cooperation

49. between the European Community and its 2014 NA Politic

Member States, on the One Party, and the

Republic of Indonesia on the Other

Protocol for the Implementation of the

Sixth Package of Commitments on

50. Financial Services within the framework 2015 NA Economic of the ASEAN Framework Agreement on Services

\begin{tabular}{lllll}
\hline 51. & Protocol 7 Customs Transit System & 2015 & NA & Economic \\
\hline 52. $\begin{array}{l}\text { ASEAN Agreement on Medical Device } \\
\text { Directive }\end{array}$ & 2015 & NA & Health \\
\hline 53. $\begin{array}{l}\text { Protocol to Amend the ASEAN Compre- } \\
\text { hensive Investment Agreement }\end{array}$ & 2016 & NA & Economic \\
\hline $\begin{array}{l}\text { Protocol for Implementing the Eighth } \\
\text { Package of Commitments to Air Trans- } \\
\text { port Services in the ASEAN Framework } \\
\text { Agreement on Services }\end{array}$ & 2016 & NA & Economic \\
\hline 55. $\begin{array}{l}\text { ASEAN Agreement on the Natural Move- } \\
\text { ment of People }\end{array}$ & 2016 & NA & $\begin{array}{l}\text { Human } \\
\text { Rights }\end{array}$ \\
\hline 56. $\begin{array}{l}\text { Second Protocol to Amend the ASEAN } \\
\text { Comprehensive Investment Agreement }\end{array}$ & 2017 & NA & Economic \\
\hline 57. $\begin{array}{l}\text { ASEAN Convention Against Trafficking in } \\
\text { Persons, Especially Women and Children }\end{array}$ & 2017 & NA & $\begin{array}{l}\text { Human } \\
\text { Rights }\end{array}$ \\
\hline 58. $\begin{array}{l}\text { Legal Framework Protocol to Implement } \\
\text { ASEAN Single Window }\end{array}$ & 2017 & NA & Economic \\
\hline 59. $\begin{array}{l}\text { Protocol to the ASEAN Charter on Dis- } \\
\text { pute Resolution Mechanisms }\end{array}$ & 2017 & NA & Law \\
\hline $\begin{array}{l}\text { Agreement on Immunity and Immunity } \\
\text { from the Association of Southeast Asian } \\
\text { Nations }\end{array}$ & 2017 & NA & Law \\
\hline $\begin{array}{l}\text { Agreement on the Establishment of a Re- } \\
\text { gional Secretariat for the Implementation } \\
\text { of ASEAN Mutual Recognition Arrange- } \\
\text { ments for Tourism Experts }\end{array}$ & 2018 & NA & Politic \\
\hline
\end{tabular}

It is demonsrated from the mapping on the development of national legislation above (since 1947-2019), that out of 61 (sixty one) international agreements, Law-Making Treaty have been ratified by Indonesia. However, there is only one law ratified and adopted to the national laws as an implication of international law taken by the Indonesian government. The product of this legislation is the Law 
Number 32 of 2014 concerning Maritime Law which essentially adopted from the 1982 UNCLOS which was ratified by Indonesia in 1985.

The other 60 (sixty) international agreements are Law-Making Treaty characteristic which are not followed up with an organic law. It means that the implementation of the international agreement provisions carried out based on the provisions of the agreement and binding since the ratification was carried out by Indonesia.

In addition, based on data in Law-Making Treaty multilateral agreements which have been followed by Indonesia, it was found that these covenants could be classified as follows:

- 42 treaties regulated economic cluster.

- 3 treaties regulated natural resource management cluster.

- 7 treaties regulated political cluster.

- 2 treaties regulated law cluster.

- 2 treaties regulated human rights cluster.

- 3 treaties regulated disaster management cluster.

- 1 treaties regulated health cluster.

- 1 treaties regulated energy cluster.

The implication of international law is taken by the Indonesian government through the formation of organic laws as the implementation of international treaties on its national law. This fact demonstated that Indonesia as one of subject in international community plays active and significant roles in promoting global needs and recognising itself as a party whose subjected under international law.

\section{Conclusions}

From 1947 to 2019 Indonesia actively get involved in international relations prooving its involvement in 302 international agreements from which international agreements were followed by Indonesia. It can be seen that 61 of them were international agreements that were Law-Making Treaty characteristic. However, from the 61 LawMaking Treaty, Indonesia has only followed up on its application in the 1982 UNCLOS agreement through the Law No. 32 of 2014 con- 
cerning Marine. Meanwhile, Indonesia refers only to the provisions of its ratification as long as the other international agreements are concerned. The large number of international treaties in the form of the Law-Making Treaty reveals that Indonesia has been further involved in economic field in international treaties. However, there are still obstacles in the future, when Indonesia is expected to become an initiator in non-economic issues, especially in the fields of human development such as education, health, human rights, and others. It has been an evidence that the goals of the Indonesian rule of law are not only economic prosperity, but also social welfare and world peace. It should be admitted that the process of internalizing international agreements is still lacking. It is supposed that the process of internalizing the values of international law can be done through national laws, particularly in the form of organic laws such as the Law no. 32 of 2014 concerning Maritime Law which is an effort to internalize UNCLOS 1982.

\section{Bibliography}

\section{Legal Documents}

Law Number 12 on 2011 concerning the Establishment of Legislation.

Law Number 24 on 2000 Concerning International Treaties.

Vienna Convention on the Law of Treaties 1969.

\section{Book and Journals}

B. Maryati, "Aspek-Aspek Hukum Perjanjian Internasional Dan Kaitannya Dengan MoU Helsinki”, Jurnal Humaniora: Jurnal Ilmu Sosial, Ekonomi dan Hukum, Vol. 1 Num. 1, 2017: 30-39.

Brolmann, Catherine. "Law Making Treaties: Form and Function in International Law”. Nordic Journal of International Law. Vol. 74, 2005: 383-404.

Departemen Luar Negeri, "Pelatihan Pembuatan Kontrak Internasional”, Surabaya. (Makalah), 2002.

Haljan, David. 2013. Separating Powers: International Law Before Na- 
tional Courts. The Hague: TMC ASSER PRESS.

Hilda, H. "Kedudukan dan Daya Mengikat Konvensi Denhaag 1954 Tentang Perlindungan Obyek Budaya Dalam Sengketa Bersenjata Terhadap Pihak-Pihak Yang Bersengketa (Amerika SerikatIrak) Menurut Konvensi Wina 1969 Tentang Perjanjian Internasional”, Jurnal Cita Hukum, Vol. 1 Num. 1, 2013.

Juwana, H. "Kewajiban Negara dalam Proses Ratifikasi Perjanjian Internasional: Memastikan Keselarasan dengan Konstitusi dan Mentransformasikan ke Hukum Nasional”, Undang: Jurnal Hukum, Vol. 2 No. 1, 2019: 1-32.

Myers, DP. "The Names and Scope of Treaties". American Journal of International Law, Vol. 51 Num. 3, 1957: 574-605.

Otto, Jean Michiel. 2012. Kepastian Hukum yang Nyata di Negara Berkembang, dalam Kajian Sosio Legal, ed. Adriaan W. Bedner et. al. Denpasar: Pustaka Larasan.

Satjipto Rahardjo, "Merumuskan Peraturan Hukum", Papers in PDIH Undip Student Reading Materials, Semarang: PDIH, 5 January 2007.

Seidmann, Robert B. et.all. 2001. Legislative Drafting for Democratic Social Change: A Manual for Drafters. First Published. London: The Hague Boston, Kluwer Law International Ltd.

Sidharta, B. Arief. 2007 Meuwissen Tentang Pengembangan Hukum, Ilmu Hukum, Teori Hukum dan Filsafat Hukum. Bandung: Refika Aditama.

Usmawadi, U. "Status Indonesia dalam Space Treaty 1967”. Jurnal Hukum \& Pembangunan Vol. 16 Num. 6, 2017: 630-637.

\section{Internet Site}

https://kemlu.go.id/b]/id/pages/hubungan_bilateral_indonesia_ dan_slovakia/1283/etc-menu accessed from 13 April 2020 at 19.00 WIB.

https: / / www.hukumonline.com/klinik/ detail/ulasan/lt4c69b1cbd0492/status-hukum-uu-rasiikasi/ accessed from 13 April 2020 at 19.00 WIB. 